\title{
Static and Dynamic Analysis of Multistory RC Building with Various Heights in High Seismic Zone
}

\author{
Ghusen Al-Kafri ${ }^{1}$, Md. Shahnewaz Sarkar ${ }^{2 *}$, Md. Shaizuddin Sarkar ${ }^{3}$ \\ ${ }^{1}$ Department of Civil Engineering, College of Engineering, Sirte University, Libya \\ ${ }^{2,3}$ Department of Civil \& Architecture Engineering, College of Engineering and Applied Science, \\ Libyan Academy, Libya \\ DOI: https://doi.org/10.21467/proceedings.4.26 \\ * Corresponding author email: shahnewaz2020@gmail.com
}

\begin{abstract}
ABSTRA C T
The earthquake ranks as one of the most destructive natural disasters recorded all over the world. It has taken millions of lives and caused vast damages to infrastructures through the ages. Since the earthquake forces are random in nature and unpredictable, the engineering tools are needed to be sharpened for analyzing structures under the action of these forces. This paper deals with the comparison of static and dynamic analysis of four RC multistory building models with different height in high seismic zone. The considered structure is modeled as 5, 10, $15 \& 20$ story structure and analyzed by commercial software Autodesk ROBOT Structural Analysis 2018. Equivalent Lateral Force (ELF) Procedure is used for static analysis and Response Spectrum (RS) Procedure is used for dynamic analysis. All the analyses are conducted according to ASCE7-10. Then results are compared based on different parameters such as: Displacement, Story Drift, Base Shear, Story Shear and Story Moment. Finally, a comparative study has been carried out between static and dynamic analysis. It was found that ELF procedure provides higher displacement, story drift and base shear compared to RS procedure. Based on the findings of the study it is recommended to use dynamic analysis (RS) instead of static analysis (ELF) specially in high rise building.
\end{abstract}

Keywords: Equivalent lateral force; response spectrum; static analysis; dynamic analysis; displacement; story drift; base shear.

\section{Introduction}

Nowadays, it is very popular for constructing low to high-rise buildings in the world due to increasing population that is required to resist the lateral dynamic loads caused by earthquake. Earthquake effects are more intense than wind effects. From past intense disaster, it can be proved that many structures are totally damaged because of earthquakes, that is natural and unpredictable, which gives intense ground shaking. Therefore, earthquake analysis and design are very important in today's world. There are various types of structural analysis used to analyse high-rise buildings subjected to seismic load such as Equivalent Lateral Force (ELF) procedure, Response Spectrum (RS) procedure, Time History Analysis etc. In the present study, ELF \& RS procedures have been carried out according to ASCE7-10.

(C) 2018 Copyright held by the author(s). Published by AIJR Publisher in Proceedings of First Conference for Engineering

Sciences and Technology (CEST-2018), September 25-27, 2018, vol. 2 .
This is an open access article under Creative Commons Attribution-NonCommercial 4.0 International (CC BY-NC 4.0) license, which permits any non-commercial use, distribution, adaptation, and reproduction in any medium, as long as the original work is properly cited. ISBN: $978-81-936820-6-7$ 
Static and Dynamic Analysis of Multistory RC Building with Various Heights in High Seismic Zone

A research work was carried out on two methods of seismic analysis namely static and dynamic for 14 story RC building under Equivalent static and dynamic loads according to Egyptian code 2012. (Mahmoud and Abdallah, 2014). Another study (Tafheem et al., 2016) investigated the seismic performance of a 10 story reinforced concrete moment resisting framed building under static and dynamic loading as per Bangladesh National Building Code (BNBC 2006). Furthermore, a study was carried out on the seismic analysis of two reinforced concrete moment resisting frame buildings $(\mathrm{G}+10$ and $\mathrm{G}+25)$ using ELF and RS (Kakpure and Mundhada, 2017).

The objective of this study is to make a comparative study between static (ELF) and dynamic (RS) analysis by investigating a reinforced concrete multistory building with different heights located in high seismic zone according to ASCE7-10. For this purpose, four models with different heights are modelled and analysed using ROBOT 2018 and the results are compared together based on five parameters: Displacement, Story Drift, Base Shear, Story Shear and Story Moment.

\section{Project Description}

For this study, a regular reinforced concrete building is considered as shown in Figure 1. The floor area of the structure is $625 \mathrm{sqm}(25 \mathrm{~m} \times 25 \mathrm{~m})$ with 5 bays along each side (each span $5 \mathrm{~m}$ ). The structure is modelled four times as 5, 10, $15 \& 20$ storied structure. Height of each story is $3 \mathrm{~m}$.

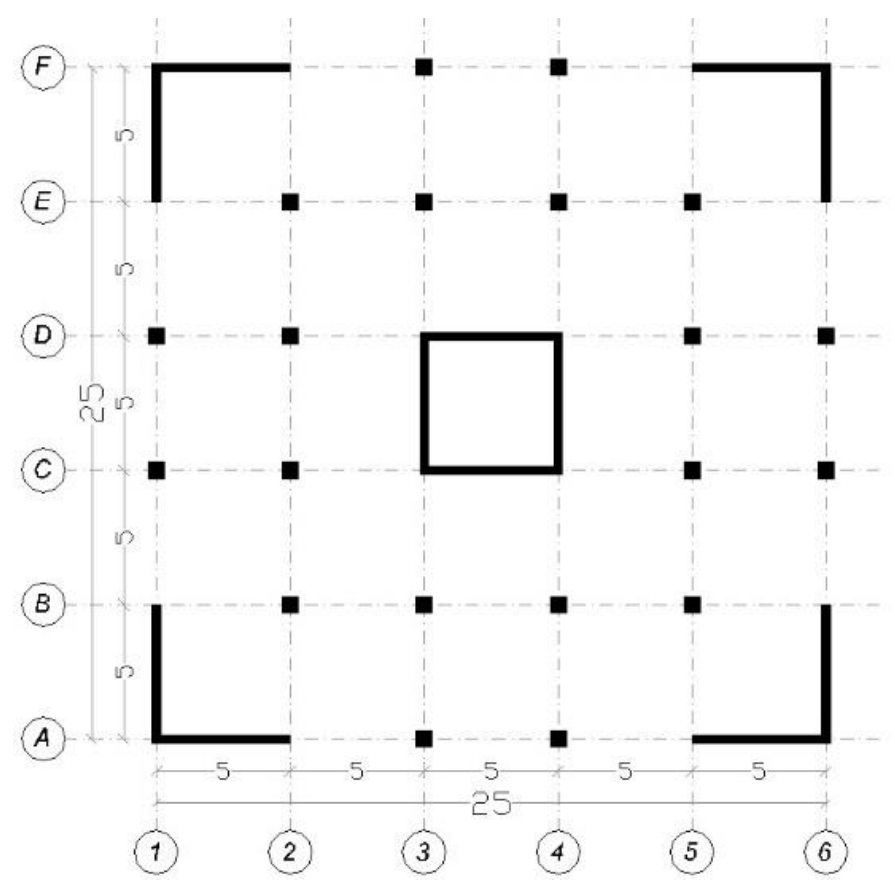

Figure 1: Plan view of considered structure

For the structures with different height, different dimensions are taken for structural elements. Table 1 shows the dimensions taken for different structural elements in this study. 
Ghusen et al., CEST-2018, AIJR Proceedings 4, pp.592-601, 2018

Table 1: Dimension of structural elements

\begin{tabular}{|c|c|c|c|c|c|}
\hline \multirow{2}{*}{ Structure } & \multirow{2}{*}{ Story } & \multicolumn{2}{|c|}{ Column } & \multirow{2}{*}{$\begin{array}{l}\text { Shear Wall Thickness } \\
(\mathrm{cm})\end{array}$} & \multirow{2}{*}{$\begin{array}{l}\text { Slab Thickness } \\
(\mathrm{cm})\end{array}$} \\
\hline & & $\mathrm{b}(\mathrm{cm})$ & $\mathrm{h}(\mathrm{cm})$ & & \\
\hline 5 Story & 1 to 5 & 40 & 40 & 30 & 17 \\
\hline \multirow{2}{*}{10 Story } & 1 to 5 & 50 & 50 & 35 & 17 \\
\hline & 6 to 10 & 40 & 40 & 30 & 17 \\
\hline \multirow{3}{*}{15 Story } & 1 to 5 & 60 & 60 & 40 & 17 \\
\hline & 6 to 10 & 50 & 50 & 35 & 17 \\
\hline & 11 to 15 & 40 & 40 & 30 & 17 \\
\hline \multirow{4}{*}{20 Story } & 1 to 5 & 70 & 70 & 45 & 17 \\
\hline & 6 to 10 & 60 & 60 & 40 & 17 \\
\hline & 11 to 15 & 50 & 50 & 35 & 17 \\
\hline & 16 to 20 & 40 & 40 & 30 & 17 \\
\hline
\end{tabular}

While designing any building, different loads acting on it play a major role. An error in estimation of these loads can lead to the failure of the structure. Therefore, a careful study of loads that are acting on the structure becomes necessary. The loads in particular area must be selected properly and the worst combination of these loads must be evaluated.

The dead load in a building should be comprised of the weight of all walls, partitions, floors, roof and should include the weight of all other permanent constructions in that building. Based on the materials used in the building, the dead load (DL) is calculated as $2.96 \mathrm{KN} / \mathrm{m}^{2}$. Live Load (LL) is taken $1.92 \mathrm{KN} / \mathrm{m}^{2}$ according to ASCE 7-10. The structure is assumed to be located in high seismic area, Los Angeles, USA. The seismic parameters used in this study are taken according to ASCE 7-10 and are shown in Table 2.

Table 2: Seismic parameters

\begin{tabular}{|l|c|}
\hline Site Class & D \\
\hline Acceleration Parameter for 1-sec Period, $\mathrm{S}_{1}$ & $0.857 \mathrm{~g}$ \\
\hline Acceleration Parameter for short Period, $\mathrm{S}_{\mathrm{s}}$ & $2.442 \mathrm{~g}$ \\
\hline Risk Category & $\mathrm{III}$ \\
\hline Importance Factor, I & 1.25 \\
\hline Long-Period Transition Period, $\mathrm{T}_{\mathrm{L}}$ & $8 \mathrm{~s}$ \\
\hline Response Modification Factor, $\mathrm{R}$ & 4.5 \\
\hline
\end{tabular}

\section{Modeling and Analysis}

All the structures with different heights are modeled and analyzed by ROBOT 2018 using Equivalent Lateral Force Procedure (ELF) as static analysis and Response Spectrum Procedure (RS) as dynamic analysis according to ASCE7-10. Figure 2 shows the modelling of different structure in software. 


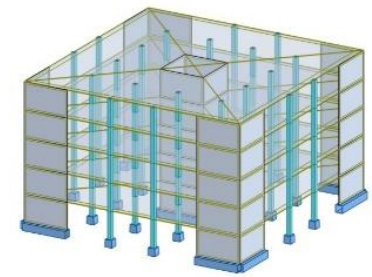

5 Story

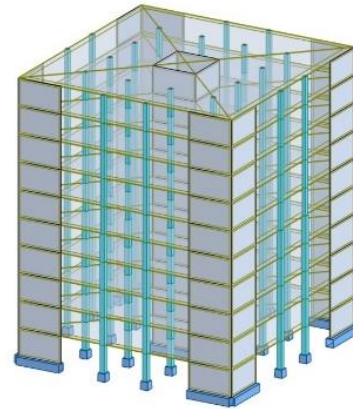

10 Story

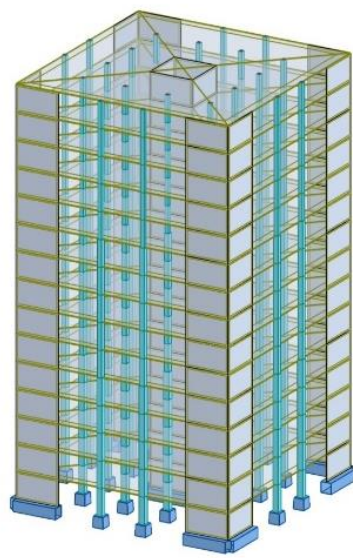

15 Story

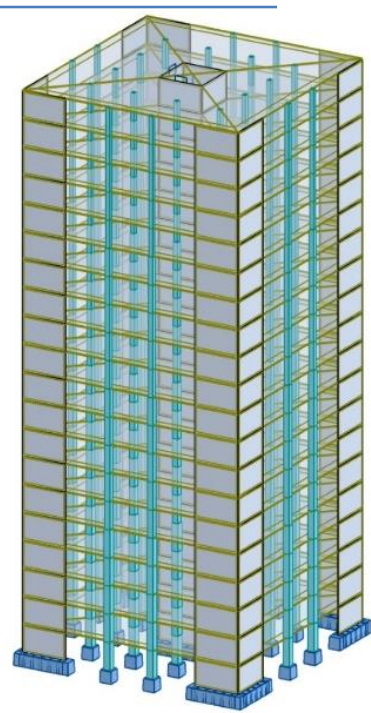

20 Story

Figure 2: Modelling of different structures in ROBOT

\section{Results and Discussion}

After performing static and dynamic analysis for all the structures with different height, the obtained results were compared based on five factors i.e. Displacement, Story Drift, Base Shear, Story Shear and Story Moment as shown in Table 3, 4 and 5.

Table 3: Comparison of static and dynamic analysis results for structures with different height

\begin{tabular}{|l|c|c|c|c|c|c|}
\hline \multirow{2}{*}{ Analysis Type } & \multirow{2}{*}{ Story } & \multicolumn{2}{|c|}{ Displacement } & \multicolumn{2}{|c|}{ Story Drift } & \multirow{2}{*}{ Base Shear (KN) } \\
\cline { 2 - 6 } & & $\mathrm{X}(\mathrm{mm})$ & $\mathrm{Y}(\mathrm{mm})$ & $\mathrm{X}(\mathrm{mm})$ & $\mathrm{Y}(\mathrm{mm})$ & \\
\hline \multirow{4}{*}{ Static (ELF) } & 20 & 626.1 & 626.9 & 41.8 & 41.9 & $28,955.96$ \\
\cline { 2 - 6 } & 15 & 278.0 & 278.3 & 24.3 & 24.4 & $26,146.06$ \\
\cline { 2 - 6 } & 10 & 88.3 & 88.4 & 11.2 & 11.2 & $22,929.92$ \\
\cline { 2 - 6 } & 5 & 9.8 & 9.8 & 2.3 & 2.3 & $13,249.58$ \\
\hline \multirow{4}{*}{ Dynamic (RS) } & 20 & 230.2 & 233.0 & 21.6 & 21.6 & $24,612.55$ \\
\cline { 2 - 6 } & 15 & 136.1 & 137.3 & 16.7 & 16.7 & $22,224.15$ \\
\cline { 2 - 6 } & 10 & 54.1 & 54.4 & 9.6 & 9.6 & $19,490.45$ \\
\cline { 2 - 6 } & 5 & 6.2 & 6.2 & 2.0 & 2.0 & $11,262.14$ \\
\hline
\end{tabular}


Ghusen et al., CEST-2018, AIJR Proceedings 4, pp.592-601, 2018

Table 4: Comparison of story shear by static and dynamic analysis

\begin{tabular}{|c|c|c|c|c|c|c|c|c|}
\hline \multirow{3}{*}{$\begin{array}{l}\text { Sto } \\
\text { ry }\end{array}$} & \multicolumn{8}{|c|}{ Story Shear $(\mathrm{KN})$} \\
\hline & \multicolumn{2}{|c|}{5 Story } & \multicolumn{2}{|c|}{10 Story } & \multicolumn{2}{|c|}{15 Story } & \multicolumn{2}{|c|}{20 Story } \\
\hline & $\begin{array}{l}\text { Static } \\
(E L F)\end{array}$ & $\begin{array}{c}\text { Dynamic } \\
(\mathrm{RS})\end{array}$ & $\begin{array}{l}\text { Static } \\
(E L F)\end{array}$ & $\begin{array}{c}\text { Dynamic } \\
\text { (RS) }\end{array}$ & $\begin{array}{l}\text { Static } \\
(E L F)\end{array}$ & $\begin{array}{c}\text { Dynamic } \\
\text { (RS) }\end{array}$ & $\begin{array}{l}\text { Static } \\
(E L F)\end{array}$ & $\begin{array}{c}\text { Dynamic } \\
\text { (RS) }\end{array}$ \\
\hline 20 & & & & & & & $2,974.31$ & $4,210.68$ \\
\hline 19 & & & & & & & $5,760.18$ & $7,362.71$ \\
\hline 18 & & & & & & & $8,360.33$ & $9,394.46$ \\
\hline 17 & & & & & & & $10,777.60$ & $10,564.48$ \\
\hline 16 & & & & & & & $13,014.92$ & $11,127.95$ \\
\hline 15 & & & & & $3,423.83$ & $4,252.66$ & $15,194.91$ & $11,323.35$ \\
\hline 14 & & & & & $6,581.28$ & $7,399.56$ & $17,191.20$ & $11,361.80$ \\
\hline 13 & & & & & $9,475.63$ & $9,451.15$ & $19,007.36$ & $11,432.03$ \\
\hline 12 & & & & & $12,110.39$ & $10,761.86$ & $20,647.19$ & $11,705.20$ \\
\hline 11 & & & & & $14,489.29$ & $11,679.13$ & $22,114.70$ & $12,298.83$ \\
\hline 10 & & & $4,221.94$ & $4,407.09$ & $16,739.76$ & $12,518.70$ & $23,491.35$ & $13,293.21$ \\
\hline 9 & & & $7,996.56$ & $7,983.76$ & $18,728.39$ & $13,459.21$ & $24,694.82$ & $14,649.53$ \\
\hline 8 & & & $11,326.96$ & $10,705.45$ & $20,460.20$ & $14,558.22$ & $25,730.36$ & $16,228.88$ \\
\hline 7 & & & $14,216.65$ & $12,836.90$ & $21,940.73$ & $15,813.74$ & $26,603.67$ & $17,900.87$ \\
\hline 6 & & & $16,669.60$ & $14,588.58$ & $23,176.18$ & $17,174.57$ & $27,321.05$ & $19,549.00$ \\
\hline 5 & $4,416.53$ & $4,169.75$ & $18,807.60$ & $16,140.21$ & $24,232.81$ & $18,614.09$ & $27,923.85$ & $21,137.28$ \\
\hline 4 & $7,949.75$ & $7,323.97$ & $20,494.13$ & $17,477.58$ & $25,045.93$ & $19,990.81$ & $28,377.28$ & $22,538.90$ \\
\hline 3 & $10,599.66$ & $9,448.09$ & $21,736.31$ & $18,523.31$ & $25,625.99$ & $21,130.25$ & $28,691.40$ & $23,627.42$ \\
\hline 2 & $12,366.27$ & $10,729.12$ & $22,543.54$ & $19,205.56$ & $25,986.35$ & $21,897.39$ & $28,878.64$ & $24,326.07$ \\
\hline 1 & $13,249.58$ & $11,262.14$ & $22,929.92$ & $19,490.45$ & $26,146.06$ & $22,224.15$ & $28,955.96$ & $24,612.55$ \\
\hline
\end{tabular}

Table 5: Comparison of story moment by static and dynamic analysis

\begin{tabular}{|c|c|c|c|c|c|c|c|c|}
\hline \multirow{3}{*}{$\begin{array}{c}\text { Sto } \\
\text { ry }\end{array}$} & \multicolumn{8}{|c|}{ Story Moment (KN.m) } \\
\hline & \multicolumn{2}{|c|}{5 Story } & \multicolumn{2}{|c|}{10 Story } & \multicolumn{2}{|c|}{15 Story } & \multicolumn{2}{|c|}{20 Story } \\
\hline & $\begin{array}{l}\text { Static } \\
\text { (ELF) }\end{array}$ & $\begin{array}{c}\text { Dynamic } \\
\text { (RS) }\end{array}$ & $\begin{array}{l}\text { Static } \\
\text { (ELF) }\end{array}$ & $\begin{array}{c}\text { Dynamic } \\
\text { (RS) }\end{array}$ & $\begin{array}{l}\text { Static } \\
\text { (ELF) }\end{array}$ & $\begin{array}{c}\text { Dynamic } \\
\text { (RS) }\end{array}$ & $\begin{array}{l}\text { Static } \\
\text { (ELF) }\end{array}$ & $\begin{array}{c}\text { Dynamic } \\
\text { (RS) }\end{array}$ \\
\hline 20 & & & & & & & $1,143.16$ & 791.00 \\
\hline 19 & & & & & & & $1,1136.82$ & $14,077.26$ \\
\hline 18 & & & & & & & $29,416.71$ & $36,541.46$ \\
\hline 17 & & & & & & & $55,426.77$ & $64,715.80$ \\
\hline 16 & & & & & & & $88,619.46$ & $95,841.93$ \\
\hline 15 & & & & & $1,315.93$ & 806.09 & $129,431.64$ & $128,513.13$ \\
\hline 14 & & & & & $12,800.99$ & $14,219.26$ & $175,905.76$ & $159,936.16$ \\
\hline 13 & & & & & $33,657.25$ & $36,764.99$ & $228,288.50$ & $189,837.86$ \\
\hline 12 & & & & & $63,096.80$ & $65,007.07$ & $286,041.15$ & $217,799.96$ \\
\hline 11 & & & & & $100,342.28$ & $96,465.39$ & $348,636.52$ & $243,860.43$ \\
\hline
\end{tabular}

Proceedings of First Conference for Engineering Sciences and Technology (CEST-2018), vol. 2 596 
Static and Dynamic Analysis of Multistory RC Building with Various Heights in High Seismic Zone

\begin{tabular}{|c|c|c|c|c|c|c|c|c|}
\hline \hline 10 & & & $1,622.68$ & 803.25 & $145,699.15$ & $130,303.77$ & $416,982.90$ & $268,966.56$ \\
\hline 9 & & & $15,739.27$ & $14,722.66$ & $196,804.40$ & $164,477.01$ & $488,064.27$ & $292,969.36$ \\
\hline 8 & & & $41,008.96$ & $39,114.70$ & $253,761.11$ & $199,630.81$ & $562,671.32$ & $317,602.45$ \\
\hline 7 & & & $76,100.49$ & $71,297.33$ & $315,801.32$ & $236,174.80$ & $640,303.13$ & $344,371.08$ \\
\hline 6 & & & $119,693.23$ & $109,344.04$ & $382,173.93$ & $274,740.72$ & $720,476.17$ & $374,719.91$ \\
\hline 5 & $1,697.47$ & 782.95 & $171,674.31$ & $152,899.15$ & $453,606.01$ & $316,857.23$ & $804,326.29$ & $410,516.61$ \\
\hline 4 & $16,305.02$ & $13,937.24$ & $228,848.50$ & $199,482.62$ & $526,714.78$ & $361,504.58$ & $888,352.36$ & $451,154.66$ \\
\hline 3 & $41,172.74$ & $36,257.31$ & $290,884.32$ & $249,383.45$ & $602,145.28$ & $409,858.20$ & $973,660.53$ & $497,472.17$ \\
\hline 2 & $73,650.71$ & $64,569.95$ & $356,452.89$ & $301,995.35$ & $679,205.10$ & $461,923.30$ & $1,059,839.85$ & $549,152.21$ \\
\hline 1 & $11,089.01$ & $96,363.00$ & $424,255.66$ & $356,609.80$ & $757,244.76$ & $517,266.35$ & $1,146,519.18$ & $605,417.63$ \\
\hline
\end{tabular}

Figure 3 \& Figure 4 show the displacement for different structures by static and dynamic analysis. From the figures it can be observed that the displacement obtained by static analysis (ELF) is higher than that obtained by dynamic analysis (RS) for all structures. Static analysis gives $58.1 \%$ to $172 \%$ higher displacement than dynamic analysis. It can be also noticed that the difference in displacement calculated by static and dynamic analysis increases with the increase of height of the structure.

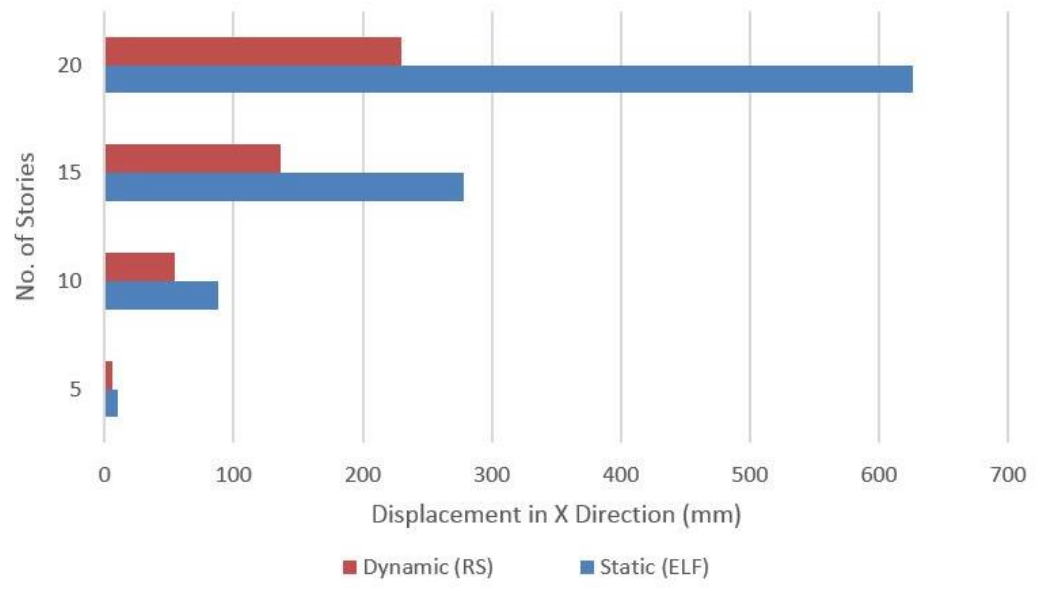

Figure 3: Displacement in X Direction by Static and Dynamic Analysis

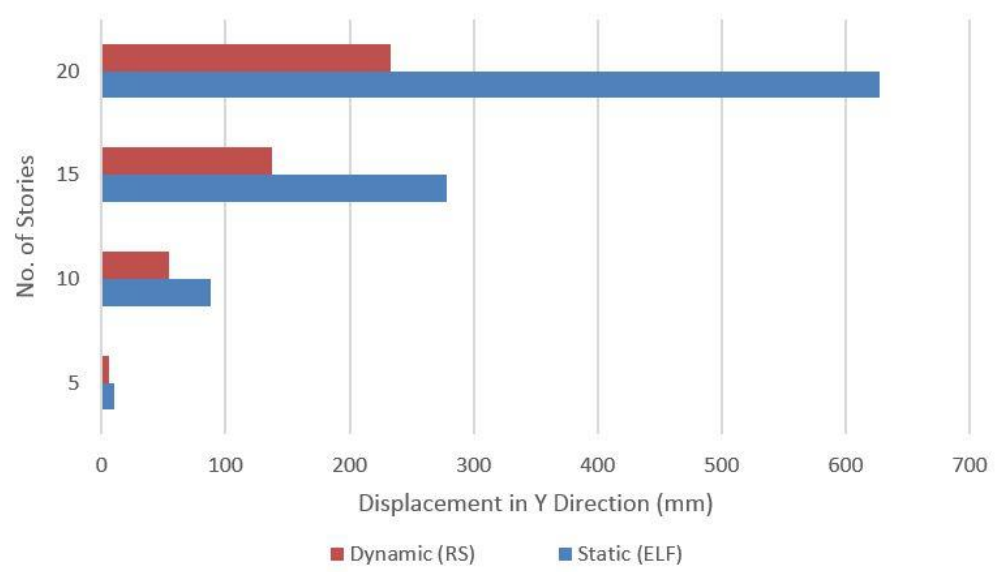

Figure 4: Displacement in Y Direction by Static and Dynamic Analysis

ISBN: 978-81-936820-6-7

Proceedings DOI: $10.21467 /$ proceedings. 4 
Figure 5 \& Figure 6 show the story drift for different structures by static and dynamic analysis. According to the code ASCE 7-10 the story drift for this study is limited to $45 \mathrm{~mm}$. It can be noticed that the story drift for all structures is within permissible limit. The figures show that the story drift calculated by dynamic analysis is lower than static analysis, where it gives 15\% to $94 \%$ less drift. It can be noticed that the difference increases gradually with the height of the structure. This indicates that static analysis may lead to uneconomical design as it gives higher drifts.

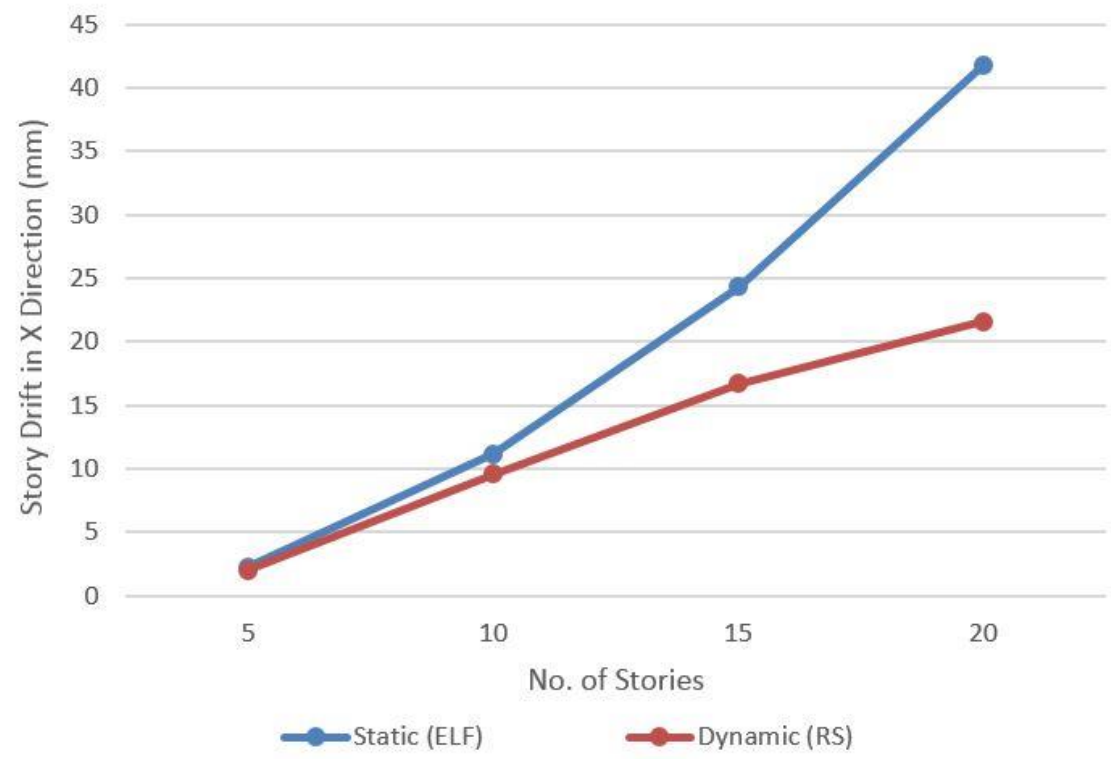

Figure 5: Drift in X Direction by Static and Dynamic Analysis

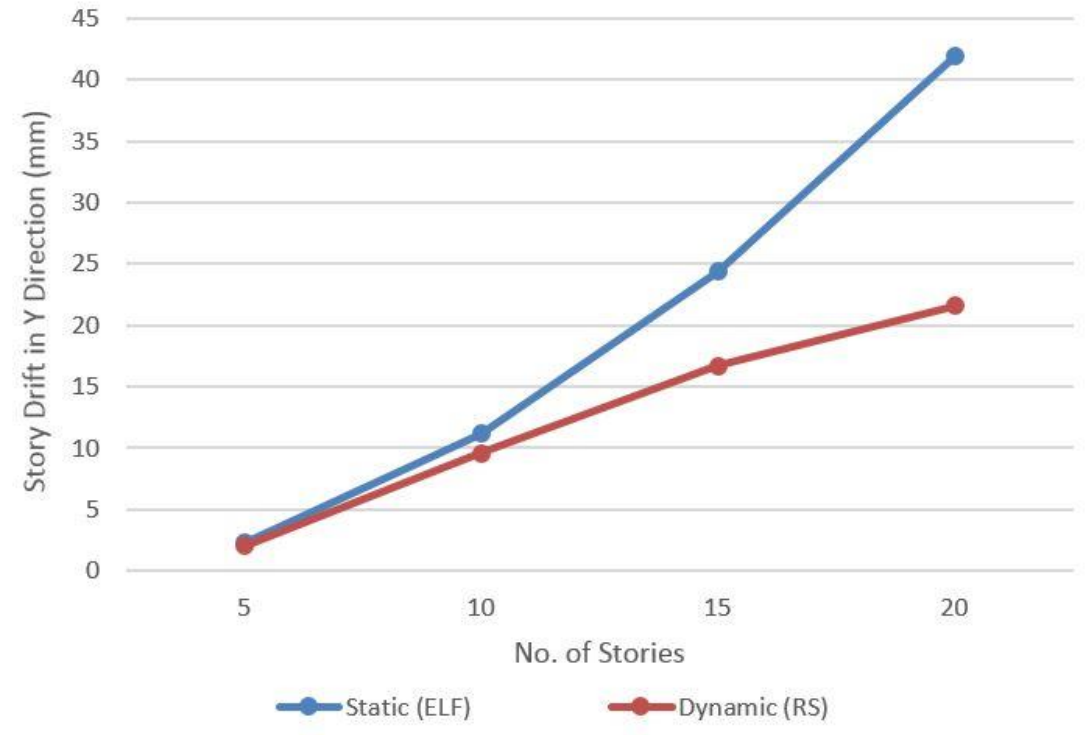

Figure 6: Drift in Y Direction by Static and Dynamic Analysis

Proceedings of First Conference for Engineering Sciences and Technology (CEST-2018), vol. 2 
Static and Dynamic Analysis of Multistory RC Building with Various Heights in High Seismic Zone

Figure 7 indicates the base shear for different structures by static and dynamic analysis. From this figure along with Table 3 it can be noticed that the base shear obtained from dynamic analysis is about $85 \%$ of static analysis. A study (Mahmoud and Abdallah, 2014) showed that the total base shear obtained from static analysis is about $8 \%$ higher than that of dynamic analysis. On the other hand, another study (Tafheem et al., 2016) found that the total base shear obtained from static analysis is about 17\% higher than that of dynamic analysis. Similarly, in the present study, it has been found that in case of static analysis, the base shear is $17.6 \%$ higher than that of dynamic analysis.

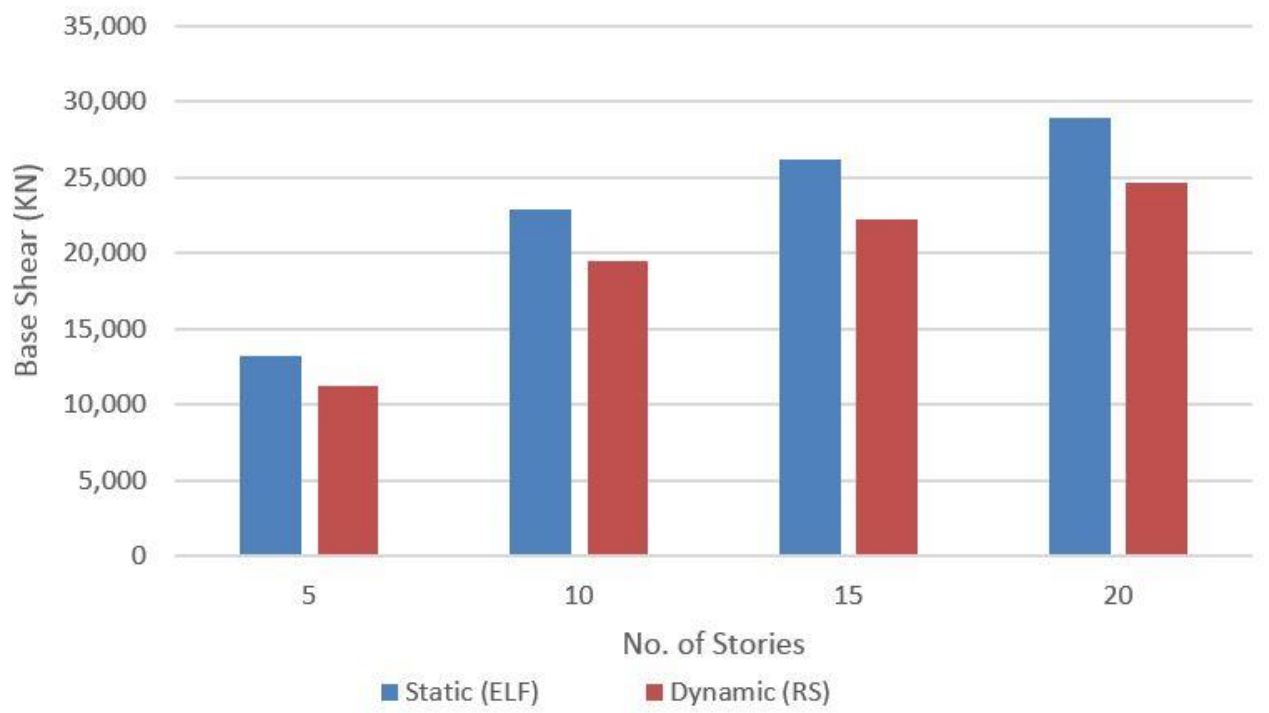

Figure 7: Base Shear by Static and Dynamic Analysis

Figure 8 shows the story shear for different structures by static and dynamic analysis. From the figure it can be observed that the story shear obtained by static analysis (ELF) is higher than dynamic analysis (RS) for all stories of all structures except for top stories of $10,15 \& 20$ storied structure, where dynamic analysis gives slightly higher story shear compared to static analysis. It can also be noticed that the difference in story shear obtained by static and dynamic analysis gradually decreases with the increase of height for 5 and 10 storied structure, while for 15 and 20 storied structure the difference in story shear is high in middle stories and decreases in upper \& lower stories. Maximum difference in story shear is $17.6 \%$ for $5 \& 10$ storied structure while the difference is $40.5 \%$ \& $79.8 \%$ for $15 \& 20$ storied structure respectively.

Figure 9 shows the story moment for different structures by static and dynamic analysis. From the figure it can be clearly noticed that the difference in story moment obtained by static and dynamic analysis gradually decreases with the increase of height of the structure. It can also be observed that the story moment obtained by static analysis (ELF) is higher (upto 116.8\%) than dynamic analysis (RS) for all structures except for some top stories of $15 \& 20$ storied structure, where dynamic analysis gives higher story moment (upto 26.4\%). 

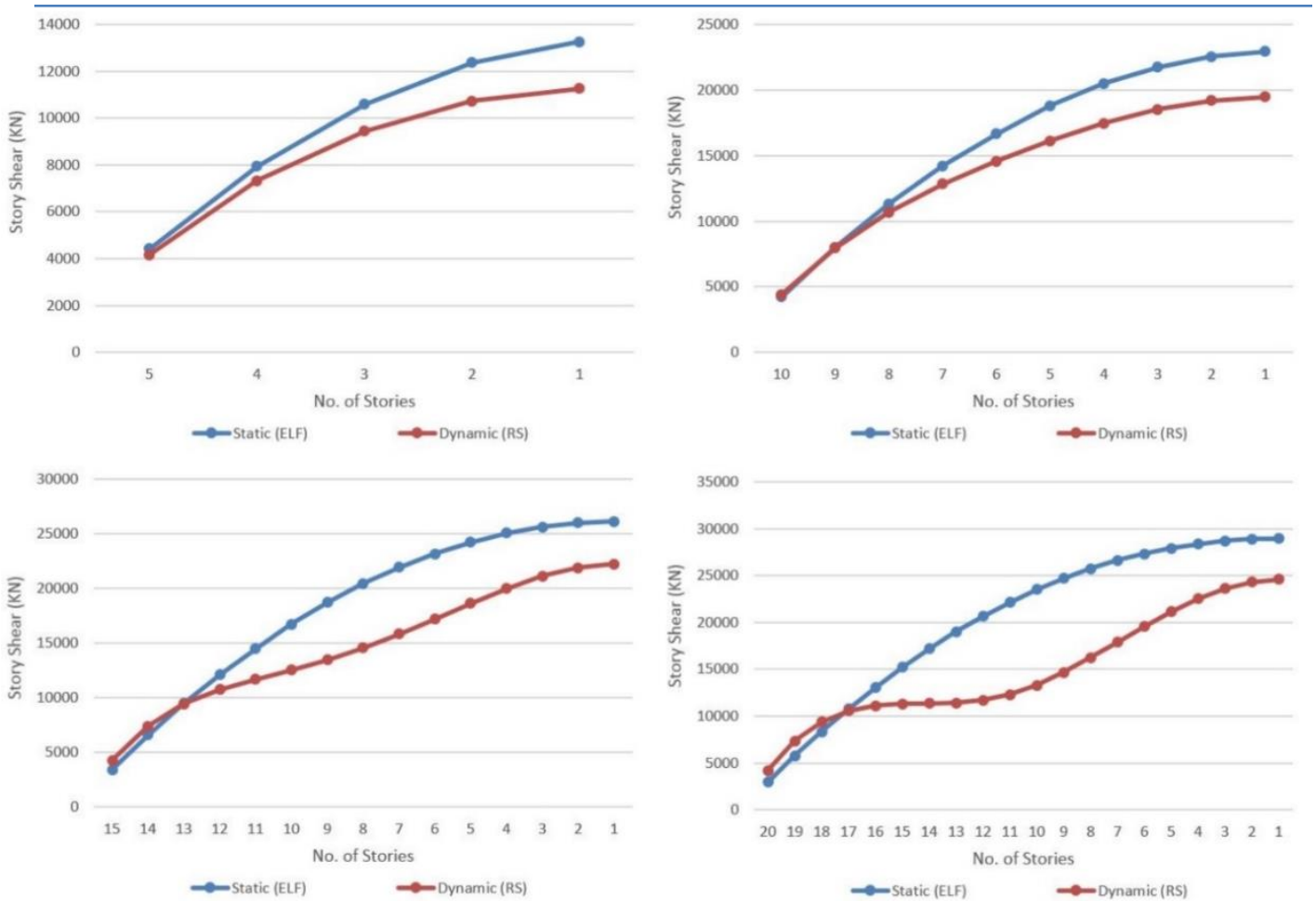

Figure 8: Story Shear for 5, 10, 15 \& 20 storied structure by Static and Dynamic Analysis
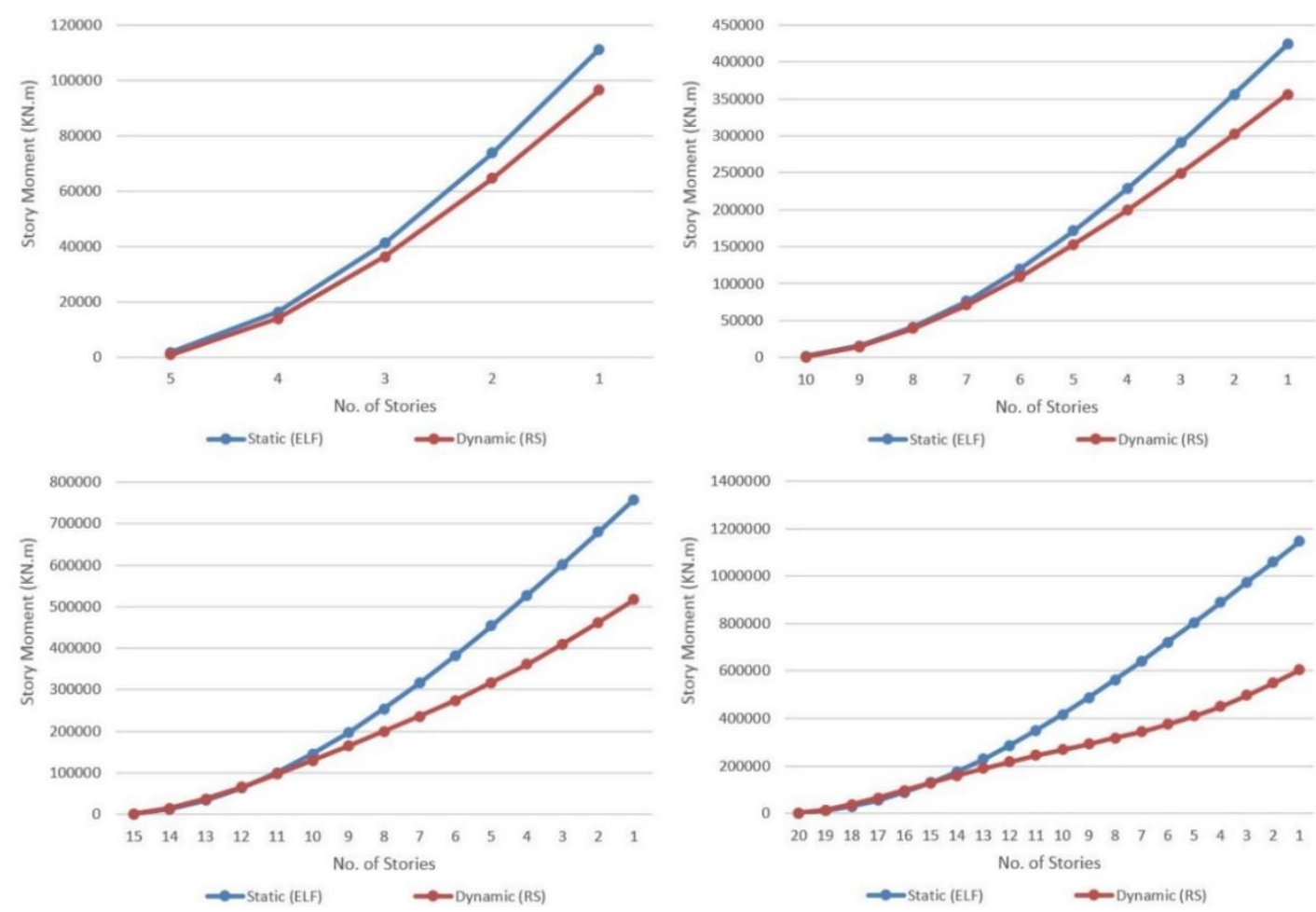

Figure 9: Story Moment for 5, 10, 15 \& 20 storied structure by Static and Dynamic Analysis

Proceedings of First Conference for Engineering Sciences and Technology (CEST-2018), vol. 2 
Static and Dynamic Analysis of Multistory RC Building with Various Heights in High Seismic Zone

\section{Conclusions}

From the results of the study it is found that Response Spectrum Analysis is an important dynamic analysis tool and it does not require high level of modelling and in the same time it provide better results compared to static analysis. Although Response Spectrum Analysis (dynamic) preferred over Equivalent Lateral Force Procedure (Static), it is very important to engineers and researchers to understand that the RS analysis is an approximate method and has limitations, as it is restricted to linear elastic analysis only. For more accurate and exact results, other advanced dynamic analysis tool such as Non-linear time history analysis can be used, but this method is more complex and time consuming. Finally, in terms of practical application, it is recommended to use dynamic analysis (RS) instead of static analysis (ELF) specially in high rise building, as it requires less computational efforts while it gives reasonably better results, leading to more economic and safe design.

\section{References}

[1] Autodesk, Robot Structural Analysis 2018, Structural Analysis Software, version 2018.

[2] B. S. Taranath, "Reinforced Concrete Design of Tall Buildings", CRC Press, New York, USA, 2010.

[3] G. G. Kakpure and A. R. Mundhada, "Comparative Study of Static and Dynamic Seismic Analysis of Multistoried RCC Buildings by ETABS," International Journal of Engineering Research and Applications, vol. 7, Issue 5, pp. 06-10, 2017. DOI: 10.9790/9622-0705050610.

[4] "Minimum Design Loads for Buildings and Other Structures" (ASCE/SEI 7-10), American Society of Civil Engineers, USA.

[5] Seismic Design Tool. Access online on 10 June 2018 at https://earthquake.usgs.gov/designmaps/us/application.php

[6] S. Mahmoud and W. Abdallah, "Response Analysis of Multi-Storey RC Buildings under Equivalent Static and Dynamic Loads According to Egyptian Code," International Journal of Civil and Structural Engineering Research, vol. 2, Issue 1, pp. 79-88, 2014.

[7] Z. Tafheem, J.I. Jihan, T. Samdanee, M.Z. Islam and A.S.M. Tarin, "Earthquake Response Analysis of a Multistoried RC Building Under Equivalent Static and Dynamic Loading as per BNBC 2006," Malaysian Journal of Civil Engineering, vol. 28, Issue 1, pp. 108-123, 2016. 